\title{
Discours
}

Revue de linguistique, psycholinguistique et

informatique. A journal of linguistics, psycholinguistics and computational linguistics

$8 \mid 2011$

Approches fonctionnelles de la structuration des textes

\section{Discourse-level structuring of information in narrative: Signalling structural, interactional and cognitive shifts}

\section{Tuija Virtanen}

\section{(2) OpenEdition}

\section{Journals}

Electronic version

URL: http://journals.openedition.org/discours/8476

DOI: $10.4000 /$ discours.8476

ISSN: 1963-1723

Publisher:

Laboratoire LATTICE, Presses universitaires de Caen

\section{Electronic reference}

Tuija Virtanen, « Discourse-level structuring of information in narrative:

Signalling structural, interactional and cognitive shifts », Discours [Online], 8 | 2011, Online since 11

July 2011, connection on 30 April 2019. URL : http://journals.openedition.org/discours/8476 ; DOI $10.4000 /$ discours. 8476

\section{(c) (i) () $\Theta$}

Discours est mis à disposition selon les termes de la licence Creative Commons Attribution - Pas d'Utilisation Commerciale - Pas de Modification 4.0 International. 

Revue de linguistique, psycholinguistique et informatique

\section{Discourse-level structuring of information in narrative: \\ Signalling structural, interactional and cognitive shifts}

\section{Tuija Virtanen}

Åbo Akademi University

Finland 



\title{
Discourse-level structuring of information in narrative: \\ Signalling structural, interactional and cognitive shifts
}

\author{
Tuija Virtanen \\ Åbo Akademi University \\ Finland
}

Discourse-level structuring of information is explored in narrative in the light of three parameters subsumed under this umbrella notion: (i) the structural concepts of "theme-rheme", connected to "position"; (ii) the interaction-oriented pair of concepts "topic-comment", grounded in the notion of "aboutness"; and (iii) the cognitively motivated gradient from "given" to "new" information, related to interlocutors' assumptions of their memory constraints as well as those of others. In each pair/gradient of concepts one member/pole - "theme", "comment", and "new" - is argued to constitute the Figure, against the (necessary) Ground of the other. The linguistic signalling of the structural, interactional and cognitive shifts in information structuring is examined in two different kinds of narratives in written French. The analysis of a short legend, in its entirety, and a narrative paragraph from a news story both point to high context-sensitivity in the signalling of the three parameters of discourselevel structuring of information, with that of the discourse level "newness" differing most markedly from the others.

Keywords: information structuring, theme-rheme, topic-comment, given-new, text strategies, sentence-initial adverbials, tense-aspect, narrative

Cet article étudie la structure informationnelle dans des textes narratifs en observant trois distinctions linguistiques que recouvre cette structure: (i) au niveau textuel, le couple «thème-rhème» défini par une distinction positionnelle; (ii) au niveau interactionnel, l'opposition «topique-commentaire» reposant sur la notion d' «à propos»; et (iii) la distinction cognitive entre information donnée et information nouvelle, mettant en jeu les présomptions des interlocuteurs sur les contraintes mémorielles de l'autre. Dans chacune de ces oppositions binaires ou graduelles, l'un des concepts joue le rôle de Figure (le «thème», le «commentaire» et l'information nouvelle) par rapport à un Fond, joué par l'autre concept (le «rhème», le «topique» et l'information donnée). Cette étude propose d'examiner la signalisation du passage entre Figure/Fond au niveau structurel, interactionnel et cognitif à travers l'étude de deux types de textes narratifs: un conte dans son entier et un paragraphe extrait d'un article de presse. Cette analyse met en évidence une signalisation hypersensible au contexte ainsi qu'une grande différence entre le niveau cognitif (donné/nouveau) et les autres niveaux.

Mots clés: structure informationnelle, thème/rhème, topique/commentaire, information donnée/information nouvelle, stratégies textuelles, adverbiaux en initiale, aspectualité, textes narratifs

\section{Introduction}

Information structuring, a bridge between grammar and text, operates on various levels in discourse. The majority of the work on information structuring has been 
concerned with the domains of grammar and local levels of text. Focusing on larger textual units and entire texts has the advantage of shedding light on the contributions of information structuring to discourse organization as a whole. Such analyses help account for the workings of the two-way traffic between text and context in terms of which discourse organization - negotiated or planned - takes place (consciously or not), for particular communicative purposes, and in particular (interrelated but always unique) communicative situations.

The terminological field of information structuring is notoriously complex: a number of distinctions - dichotomous, gradient or scalar - are in use, including various combinations of terms and notions, at times conflated into one. This situation places high demands on the choice of terms for particular studies in line with Lyons' (1963) principle of "material adequacy". To a large extent the discrepancies can be accounted for by the different traditions and purposes characterizing studies of information structuring across languages. Yet, they also testify to the multifaceted nature of information structuring - an umbrella notion under which several parameters can be singled out. Such parameters may be concomitant (perhaps partly explaining their occasional conflation in the literature), but more importantly for an understanding of information structuring as a whole, they can be shown to function in very different ways in texts, at times conflicting with one another.

The present paper focuses on three different parameters of information structuring on the discourse level, related to structural, interactional and cognitive concerns. In line with Östman and Virtanen (1999), each pair of concepts is approached through the lens of Figure-Ground distinctions, pervasive in many ways in the interpretation of discourse organization. Hence, one member of the pairs of concepts associated with the three different parameters of information structuring at hand, is argued to constitute a Figure-like, salient concept, against the indispensable Ground of the other. The three parameters of information structuring are presented in section 2, below.

The goal of this paper is to explore the linguistic signalling of discourse-level shifts in terms of these three parameters of information structuring, in written narratives of two kinds in French. The analysis supports the view that the three parameters also have separate functions on the discourse level. Further, the structural, interactional and cognitive Figures are related to different profiles of discourse organization. The study also contributes to our understanding of the discourse functions of temporal and spatial signals in narrative as well as other linguistic devices such as referential choices, tense-aspect variation and connectors. Section 3 touches upon narrative, its prototypical text strategies and other characteristics, in view of the analyses of discourse-level linguistic signalling undertaken in section 4 .

\section{Three parameters of information structuring}

Östman and Virtanen (1999) approach the umbrella notion of "information structuring" in the light of three parameters: (i) the structural pair of concepts 
"theme-rheme", related to position; (ii) the interaction-oriented pair of concepts "topic-comment", based on "aboutness"; and (iii) "given-new" information, the two poles of the scale or gradient of information connected to cognitive concerns in terms of memory constraints. Apart from their usual domain in the literature, extending over a clause, a sentence, or two, these three parameters of information structuring can be applied to the discourse level. For a discussion of the differences between Halliday's (1985) systemic-functional approach and the present way of construing the parameters, see Östman and Virtanen (1999: 93, I06-107).

One of the members in each pair of concepts, Östman and Virtanen (1999) argue, is salient, or Figure-like. Hence, in a prototypical declarative clause of English, (i) "theme" is the salient member of the structural pair of concepts, the entry-point to the rest of the clause; (ii) "comment" is the salient member of the interactional pair, related to end-weight; and (iii) "new" information is the Figure-like goal of the message, indicated by its prosodic nucleus.

Theme can thus be interpreted as a linearization decision made by the textproducer, in a particular communicative situation, for a particular communicative goal - the choice of an entry-point from which to approach what follows. The less salient concept of the structural pair of notions, rheme, comprises the "rest". This strictly positional sense of theme can be applied to different languages irrespective of their structural preferences as to what is placed first in a clause or sentence.

Comment is geared towards interaction, to ways of facilitating interlocutors' understanding of one another. This is so because interlocutors greatly benefit from sharing an interpretation of what a clause, sentence or longer stretch of text is about (topic) and what information is provided concerning it (comment). It is important for interlocutors to get across their weighty comments in the unfolding discourse, in order to monitor interaction in the joint process of discourse construction. Adhering to the principle of end-weight is an interactionally successful strategy, present both in English and French. But it is the weightiness of the information, rather than its position, that characterizes the salient member of this parameter.

New information is related to cognitive concerns, to interlocutors' assumptions of one another's memory constraints at a given stage in the discourse. Newness is expected to coincide with the interlocutors' main inferencing effort: processing the salient new information, not yet activated, and relating it to the current (semi-)activated information in (episodic) memory (cf. e.g. Chafe, 1994; Van Dijk, Kintsch, 1983). Assigning an element the value of new is not related to its position, even though end-weight and end-focus will prototypically cooperate in many languages, including English and French. In others, again, prosody is not the primary means of signalling newness. In Finnish, for instance, various particles can serve this function, and the language also readily conforms to the strategy of putting "crucial information first" (CIF, see Enkvist, 198I), even in writing (for examples, see Östman, Virtanen, 1999). Newness, interpreted as inactivated information, is separate from both comment (weightiness) and theme (entry-point). 
In what follows the three parameters of information structuring are applied to the discourse level, to explore the linguistic cues of the structural, interactional and cognitively grounded shifts in written narrative. After a perforce brief summary of the main linguistic characteristics of narrative in section 3, section 4 presents two illustrative analyses of different kinds of narratives, examining information structuring at the level of the entire text and within a typographic paragraph. Apart from typographic paragraphs, however, texts also consist of units of other kinds; at this point a note on the notion of "text(ual) unit" is thus in order.

It is important to observe that typographic units such as sentences and paragraphs may, but need not, coincide with units based on textual phenomena such as, for instance, the overall schematic structure of narrative, topic management, (fore) grounding and point of view. The two are thus to be kept apart in actual analysis, even though their relationships may be worth investigating for particular purposes. In what follows, a "textual boundary" refers to one between text(ual) units based on textual phenomena, not to the division of the text into typographic paragraphs. Secondly, it may be expedient or desirable for some purposes to regard larger blocks of text as the sum total of the smaller parts included in them; typographic paragraphs, for instance, are made up of a series of sentences. But units based on textual phenomena are not constituted in such a straightforward manner. While, for instance, clausal and sentential topics tend to be related to the discourse topic, we cannot in any simple fashion single out the discourse topic by adding them all together, even though we are likely to get a rough idea of the main building blocks of a narrative such as its participant orientation and temporal structuring. The issue is raised even more acutely if we consider units of narrative pertaining to the relative foregrounding and backgrounding of events, the intriguing interplay of plot and evaluation, climactic structure and multiple shifts in point of view.

\section{Narrative strategies}

Narratives are dual-strategy texts, manifesting a temporal as well as a participantoriented text strategy. Linguistic signals of text strategies appear at the outset of their clause, sentence or the textual unit that they serve to introduce, after a textual boundary of some kind - or close to such an initial slot. But elements placed early in their textual unit can be expected to contribute also to other dimensions of discourse because of their salient position, including, one might hypothesize, at least some of the work of signalling structural, interactional and cognitive shifts in information structuring on discourse level (for discussions of text strategies, see e.g. Enkvist, 1987; Virtanen, 1992a; for (fore)grounding in narrative, see e.g. Wårvik, 1990; for discourse framing in French, see e.g. Charolles et al., 2005).

As the temporal text strategy can be signalled through a chain of sentence-initial adverbials of time, such markers might also be good candidates for indicating shifts in information structuring on the discourse level, because of their strategic placement 
at the outset of new textual units. Another cue, manifest early in the sentence, might be variation in referential choice regarding a continuous (group of) participant(s) in subject position, the repertoire consisting of pronominal and zero anaphora as well as full noun phrases of various kinds. Other aspects of the participant-oriented text strategy, such as breaks in participant continuity or the degree of individualization of participants, might also be of interest to the present analysis. Still another good candidate would seem to be tense-aspect variation, characteristic of narrative texts. In contrast, connectors are rare in narrative, as compared to non-narrative texts; yet, their presence, also predominantly initial in the sentence, would thus seem to be conspicuous enough to constitute another way of contributing to the signalling of information-structural shifts.

The primary criteria for narrative texts are their contingent temporal sequentiality and participant orientation. Other criteria include, for instance, causality and tellability. Narrative has a particular overall structure, and it may be climactic, manifesting a peak profile, as well as a full repertoire of options for point of view. Narrative texts can realize a range of different discourse functions, which affect their linguistic characteristics. And narratives can be found in many different genres, even though the prototypical narrative is a story of some kind, concerned with imaginary or actual events. A substantial amount of literature exists on narrative; for discussions of the forms and functions of narrative, see e.g. Labov, 1972; Longacre, 1983; Ochs, Capps, 200I; Virtanen, I992a, 1992b, 20I0; for genre, see e.g. Swales, I990; Virtanen, 2010. For the present purposes it will suffice to focus on the main linguistic properties of narratives, to the extent that these may be expected to contribute to the signalling of shifts in the information-structuring parameters under attention.

\section{Illustrative analyses}

This section explores the linguistic signalling of information structuring on the discourse level in two different kinds of narrative texts in written French: (i) a legend, an evocative text analysed in its entirety; and (ii) a paragraph from a news story, an informative text. The common denominator of the two sample texts, the shared narrative text type, is related to form. The first of these texts also serves the narrative type of discourse, related to function, while the second realizes the expository discourse type, on the functional level (for a discussion of text and discourse types, and genres, see e.g. Virtanen, 1992b, 20IO). The differences pertaining to discourse type and genre are expected to affect the linguistic signalling of information-structuring shifts on the discourse level. And in line with the bidirectional relationship between text and context, such markers, in turn, contribute to the construction of text/discourse type and genre. Yet, the shared narrative type of text is also likely to be revealed through some degree of parallelism in discourse marking between the two sample texts. The distinction between evocative and informative texts is based on the assumed nature of their relation to interlocutors' constructions of text worlds around them (cf. Enkvist, 1985, 1989). Table I summarizes the main characteristics of the two sample narratives. 


\begin{tabular}{|l|l|l|l|l|}
\hline $\begin{array}{l}\text { Text type } \\
\text { (form) }\end{array}$ & $\begin{array}{l}\text { Discourse type } \\
\text { (function) }\end{array}$ & $\begin{array}{l}\text { Genre } \\
\text { (text-external } \\
\text { label) }\end{array}$ & $\begin{array}{l}\text { Text world } \\
\text { (relation) }\end{array}$ & $\begin{array}{l}\text { Textual scope } \\
\text { (of analysis) }\end{array}$ \\
\hline narrative & narrative & legend & evocative & entire text \\
\hline narrative & expository & news story & informative & paragraph \\
\hline
\end{tabular}

Table 1. Characterization of the illustrative sample narratives.

\subsection{A simple story}

To explore how the discourse-level shifts in information structuring are signalled in narrative, let us analyse a telling (rather than a translation) of a Finnish legend, written to be read by, or aloud to, children (Ragache, 1989: 20). For clarity, the text is analysed as distinct from its visual and verbal context in the volume in which it appears; thus decontextualized it will still retain its genre identity, as an autonomous legend.

\section{[1] Le chêne géant}

Il fut un temps où la création du monde semblait achevée. Les continents, bosselés de montagnes, creusés de vallées, recouvraient une partie de notre planète; les étoiles parsemaient la voûte céleste, le soleil et la lune se montraient dans le ciel à tour de rôle, hommes et animaux vivaient, parlaient, mangeaient et se multipliaient. Pourtant il manquait encore, par-ci, par-là, quelques éléments...

À cette époque lointaine, trois jeunes filles plantèrent un chêne. Elles étaient amoureuses, la date de leur mariage approchait: peut-être espéraient-elles que cet arbre leur porterait bonheur? Nul ne le sait...

Les années passèrent. Le chêne était devenu l'un des plus beaux de la région. Personne ne se souvenait plus des jeunes filles qui l'avaient planté, mais il grandissait toujours, dépassant la cime des arbres les plus hauts. Au début, les hommes, fiers de ce chêne géant, venaient de loin pour l'admirer, puis, voyant que sa croissance n'avait pas de fin, ils s'inquiétèrent.

Un jour, un petit nuage poussé par le vent s'accrocha aux branches du chêne et y resta prisonnier: la cime avait atteint le ciel, ce qui entraina une série de catastrophes. En effet d'autres nuages vinrent se jeter dans la ramure de l'arbre, qui formait une barrière infranchissable. Le climat se détériora, et la situation s'aggrava lorsque le soleil et la lune à leur tour trouvèrent leur route barrée. Les deux astres, masqués en permanence par les nuages accumulés sur le chêne, ne parvenaient plus à éclairer la Terre. Les ténèbres et le froid s'installèrent...

Les hommes essayèrent bien d'abattre l'immense chêne, mais aucun d'entre eux ne réussit à en entamer le tronc. Découragés, ils abandonnèrent tout espoir...

Alors on vit surgir de la mer un tout petit homme, haut comme trois pouces, tout noir de poil et de peau, et muni d'une minuscule hache d'or pur. Il s'approcha du chêne qui était des milliards et des milliards de fois plus grand que lui et l'abattit d'un seul coup. Aussitôt, les nuages délivrés reprirent leur course, et les astres 
éclairèrent à nouveau la Terre. Mais quelques étoiles restèrent prisonnières de la ramure du chêne, qui s'était couchée dans le ciel. Ainsi naquit la Voie lactée.

In what follows the three parameters of information structuring are first singled out on the discourse level (4.I.I), their linguistic markers in the text are then put under the lens (4.I.2), to round off with a discussion of the context-sensitivity of the signalling (4.I.3).

\subsubsection{Discourse-level application of the three parameters}

Starting with the structural parameter of information dynamics, its salient discourselevel theme provides an entry-point to what follows, thus constituting a Figure at the initial stage of the discourse. Of the three parameters, the choice of a starting point is most clearly oriented towards the text-producer's decision concerning perspective even though it is made in view of a particular communicative goal, involving audience design. The discourse-level theme of a narrative provides an "orientation" for the rest of the text (for the overall structure of narrative adopted in the present analysis, see Labov, 1972). The above text manifests an orientation $a b$ ovo, opening with a genre marker il fut un temps où (cf. il était une fois; once upon a time, in fairy tales) and continuing until the end of the third paragraph. The title of the story is an autonomous unit in the discourse. The orientation part is the salient discourse-level theme while the discourse-level rheme, the rest of the text from the fourth paragraph onwards, constitutes what is at this stage the less conspicuous member of the structural pair of notions. A narrative starting in medias res would, in contrast, rather conform to the CIF principle, that of putting crucial information first (Enkvist, 198I, 1989).

The interactional Figure, the prominent member of the topic-comment pair of notions, is the comment, coinciding with end-weight in prototypical sentences. Comment is oriented towards interaction in the sense that it is strongly influenced by interlocutors' expectations of how the text unfolds, specifying what weighty elements are to be incorporated into the text world (assumed to be) under construction. In the present analysis the discourse level comment is concomitant with the "peak" of the climactic narrative (see Longacre, 1983). In this near-prototypical story, the peak coincides with the shift from the "complicating action" part to the "resolution" (cf. Labov, 1972). The turning point at the outset of the last paragraph is thus interpreted as the beginning of the discourse-level comment; this is the part of the text conveying the weighty information concerning the discourse-level topic, as it provides a solution to the problem at hand.

Alternatively, other dimensions of narrative can be considered to represent the discourse-level comment as the concept is not tied to position in the way the theme is. Hence, in a different analysis altogether, it is possible to regard as the discourse-level comment all of the evaluation found in the story, interspersed in the text through signals of various kinds (for evaluation in text, see e.g. Hunston, Thompson, 200I). In this view the discourse-level topic would thus be the plot. 
Evaluative elements, however, tend to cluster at the peak (see e.g. Labov, 1972; Fleischman, 1990). In the present analysis I choose to interpret the discourse-level dichotomy between topic and comment in terms of the peak profile of the narrative, the interactionally salient, weighty comment thus coinciding with the culmination of the text.

The third parameter, the scalar notion of given-new information, is most directly related to cognitive concerns, in terms of assumptions of accessibility in memory. As on the sentence level, the discourse level newness refers to information that is not assumed to be activated or semi-activated in (episodic) memory (cf. e.g. Chafe, 1994; Van Dijk, Kintsch, 1983; Prince, 198I). Such information is profitably integrated into the discourse in as smooth a way as possible, and the Figure-like newness therefore tends to be viewed against an activated or semi-activated Ground, both at sentence-level and in (larger portions of) text, the two taking turns for the purposes of optimal processing in memory. A good candidate for discourse-level newness would thus be the foregrounded parts of a narrative, the cluster concept of "grounding" constituting an extremely context-sensitive phenomenon in texts (for grounding markers in narrative, see Wårvik, 1990, 2004).

In the present analysis, however, newness is connected with the unexpected twist in the last but one sentence of the text: the information conveyed in this sentence has not been previously activated by the text or its heading. It constitutes the main motivation provided in the text for tellability, responding to the question "so what?" (cf. e.g. Labov, 1972; Ochs, Capps, 200I). The Labovian "coda" in the final sentence serves to reinforce the focal point, the raison d'être of the story, while also closing the narrative frame of time. The coda refers to the emergence of the Milky Way, activated by the multimodal context of the page on which the text appears. In terms of the particular genre and wider discourse context of the text, the book in which the story is included activates assumptions concerning myths and legends of the creation of the world. The new information of this particular story will therefore be "unused", rather than "brand-new", for the reader/listener who can identify the connection of the story to its broader context (for these categories, see Prince, 198I). Rather than semi-activated, however, unused information, too, is inactivated (but identifiable) at the point at which it appears. This part of the text functions as the focal point of the story, where the readers' and listeners' main inferencing effort is expected to take place.

To sum up the analysis, the focal point at the end of the story is interpreted as the cognitively salient part of the narrative, as newness, while the peak of the narrative is regarded as the weighty discourse-level comment. Theme, as the entry-point, encompasses the orientation, extending until the starting point of the narrative proper. The discourse-level new is characteristically small in size, unlike theme and comment, which both encompass long stretches of the narrative. But in each case, these Figure-like notions are smaller in size than their indispensable 
but undifferentiated counterparts. Having identified the structural, interactional and cognitive shifts in the discourse-level information structuring of the sample narrative, let us now examine what linguistic signalling, if any, is present at such points in the text.

\subsubsection{Linguistic signalling of shifts in discourse-level information structuring}

A thorough analysis of the text is beyond the scope of the present paper, our concern being with the aggregate of linguistic markers signalling informationstructuring shifts on the discourse level in narrative. Structuring information on the discourse level is a matter of selecting an entry-point (theme), singling out the weighty part (comment), and conveying the raison d'etre of the story (new). The three parameters, based on structure, interaction, and cognition, were likened above to three different discourse dimensions: narrative schema, peak profile, and tellability. Mention was made of alternative analyses of the discourse-level topic-comment and given-new distinctions; these will not, however, be followed up in the present paper.

Let us approach the shifting information-structural landscape from the perspective of the interplay of linguistic cues of various kinds. Signals of textual boundaries are usually placed at the outset of new textual units, but endings, too, can disclose an approaching shift to another unit in the text. Attention will thus be paid to the textual zone immediately preceding and following the informational shifts identified in 4.I.I, above.

The entry-point to the narrative is through a genre-marker il fut un temps où..., activating the temporal text strategy. The first paragraph then describes the locative setting and ongoing activities, ending in the statement of a problem. The first sentence of the second paragraph can be expected to open the narrative proper, the complicating action part. But the textually given adverbial marker $\grave{a}$ cette époque lointaine, separated from its sentence with a comma, is semantically unfocused, and it soon turns out that the group of three girls - possible candidates for a participant-oriented text strategy - are minor characters only (props), serving to introduce into the text its main participant, the giant oak-tree, referred to in the title of the story. Yet, this sentence includes the first passé simple verb of the text, and variation in tense-aspect is the obvious, deictic candidate for the signalling of temporal relations in narrative as well as of the relative foregrounding and backgrounding of events. But the absence of a second passé simple verb blocks the interpretation of the second paragraph as constituting the opening of narrative proper, and the text thus continues under the guise of an orientation.

The next verbal signal of temporal succession takes the form of a transitional sentence: les années passèrent, followed by a description of the state of affairs years later. There is a promise of a chain of actions and events in the sentence-initial au début but the tense soon makes it clear that the boundary between the discourse-level theme and rheme has not yet been reached; this description of on-going activities is 
still part of the orientation of the story. The undifferentiated reference to men (les bommes) is not explicit enough to be able to sustain expectations possibly raised of a sequence of events and actions, which are, in their turn, unfocused and repeated. The effects of the sentence-initial adverbial marker au début, and its follow-up partner puis, thus quickly fade away.

Yet, there are at this point several indications of closure. First of all, the sentence starting with au début, followed by puis a little later, may be interpreted as an embedded "mini-telling" (cf. Lindholm, 2oro), serving a descriptive function here. Its outcome highlights the end of the orientation part of the text by incorporating the passé simple of a private verb: ils s'inquiétèrent. Another marker of text-strategic closure is related to the paragraph-final signalling of affect, linguistically (consider the metadiscursive questions and comments addressed by the implied story-teller to the implied audience, e.g. peut-être [...]? Nul ne le sait... at the end of the second paragraph) and typographically (witness the use of three dots at the end of paragraphs I, 2, 4 and 5). The discourse-level theme shows deviation by being closed without added typographic load, abruptly.

The Ground-like discourse-level rheme starts at the outset of the fourth paragraph, at the major text-structural boundary between orientation and complicating action. A prototypical text-strategic signal in narrative, the sentence-initial adverbial of time un jour, followed by a comma, marks the major textual boundary between orientation and narrative proper (cf. Virtanen, 1992a; for a detailed analysis of the adverbial un jour, see Charolles, 2006). It is a focused marker, forcing the reader to leave the very long periods of time behind in anticipation of a particularized and foregrounded event to take place. A new, individualized participant is introduced (un petit nuage), and the verbs are now predominantly in the passé simple. There is enough of temporal juncture between the subsequent events leading to climate change, for the paragraph to be interpreted as foregrounded in the narrative, before the text returns to the description of the outcome of the series of events and the vain efforts of the undifferentiated participants (les hommes) in trying to restore what is left of the world after the environmental disaster. The three paragraphs subsumed under the discourse-level theme manifest gradually rising levels of "communicative dynamism" (Firbas, 1992) as the reader proceeds towards the starting point of the narrative proper. And the discourse-level rheme, the rest of the text, is expected to show a continuous increase in communicative dynamism from that point onwards. But within the rheme of this narrative there are other information-structural shifts that attract attention, those based on interactional and cognitive concerns.

The peak of the narrative is here interpreted as its discourse-level comment, the locus of the interactionally important, weighty information thus being found in the last paragraph. The turning point of the story is introduced by the sentence-initial alors, another prototypical text-strategic signal in narrative. It is part of the chain of signals of the activated temporal text strategy; yet, 
this marker is different from the preceding ones in size (small) and temporal focus (narrow). Unlike in previous sentence-initial adverbials of time, there is no lexical content; alors is a mere marker of a temporal juncture. This signal is followed by a presentational construction introducing a new, individualized and human-like participant (un tout petit homme), described in detail, including the instrument he is carrying. The participant-oriented text-strategic continuity (un tout petit bomme - il - Ø) and a sequence of two passé simple verbs of action realize the foregrounded comment part of the discourse, its culmination leading to the successful outcome introduced by aussitôt. The comment part of the text thus exhibits a prototypical combination of narrative strategies in explicit form as well as a change in the pace and rhythm of the telling into a rapid, focalized sequence of actions depicted in several sentences, the relatively brief event thus being stretched out unlike previous events included in the text. For a discussion of the linguistic means of creating "rhetorical underlining" in peak episodes, see Longacre (1983). The discourse-level comment relies on the activated text strategies by showing deviation from their markers in the preceding text; in this light, its relation to them can be characterized as parasitic.

At this point the temporal text strategy has done its job: we have seen vast, backgrounded periods of time, focalized points of time, and sequences of adjacent and less adjacent actions and events. But the raison d'être of the story is still missing. The signal at the outset of the focal part of the narrative is completely different from the preceding ones: the connector mais. It is soon followed by another connector, ainsi, which introduces the coda, hence bringing the reader back from the story-time to the time of reading. Since connectors are few in narratives, as compared to non-narrative texts, their presence is conspicuous in a slot which is more commonly occupied by temporal or participant-oriented signals. Mais introduces discourse-level newness, thus singled out from the given background of the completed series of events and actions. The main inferencing effort is assumed to take place as the inactivated information is conveyed at the focal point of the story.

\subsubsection{On the context-sensitivity of linguistic signalling}

What the above analysis of a short narrative demonstrates is the very high contextsensitivity of the signalling of shifts in information structuring. A switch to passé simple is conspicuous after something else; maintaining such verb forms will sustain the continuity of a foregrounded episode. A temporal signal, combined with a highly individuated, new participant, can affect the interpretation of the textual boundary thus introduced as a major one. A non-temporal marker in a narrative that makes use of explicit temporal signals of text strategy will carry text-organizational meaning, and different kinds of temporal markers (such as those relating to points of time, periods of time, temporal (non)adjacency, simultaneity, flashbacks and flashforwards) as well as differences in the frequency of temporal markers will be interpreted in the context in which they appear, in relation to 
other markers and the continuous flow of time, which is here taken for granted unless otherwise indicated.

Sentence-initial adverbials of time function in the service of text structuring, as strategic signals of coherence, text segmentation, and hierarchic relations between units of text, at macro and micro levels in the narrative (cf. Virtanen, 1992a, 2004). Positioned in the sentence-initial slot, temporal signals may, however, also contribute to other dimensions of discourse, in a highly contextsensitive manner, in cooperation with other linguistic cues present in the text. In the sample narrative, text-strategic adverbials contribute to the signalling of information structuring at the level of the entire text, by indicating its structural and interactional shifts. The genre-marker activates expectations of a temporal text strategy, and after indications of closure of the discourse-level theme, the beginning of narrative proper is marked by the prototypical adverbial un jour. The onset of the weighty discourse-level comment is signalled through an adverbial of time that is semantically focused and small in size, hence differing from the earlier signals in the text-strategic chain. Alors is a minimal signal of temporal juncture, and the absence of a comma allows for a swift transfer into the subsequent presentational construction. In contrast to the discourse-level theme-rheme and topic-comment shifts, the signalling of newness is altogether different: in the sample text newness is indicated by a connector, rare in narrative, followed by another one introducing the coda.

Breaks in participant continuity add to the signalling of shifts of the three kinds, a little later in the sentence. The presentational construction at the outset of the discourse-level comment serves to highlight the introduction of a new, highly individualized, human-like participant, different from the other (groups of) participants that function as props, or represent non-human entities of the great forces of nature that are central to the discourse topic. Further, variation in tense-aspect contributes to the relative foregrounding of events. The passé simple verb indicating a mental state at the closure of the discourse-level theme differs from the preceding verbs that are predominantly in the imparfait. Another signal of closure at the end of the discourse-level theme is the absence of paragraph-final affect.

Figure I summarizes the analysis of the linguistic signalling of informationstructural shifts of three different kinds in the sample text. The Figure-like member of each pair of the information-structuring concepts is underlined and placed on the left-hand side while their less salient members appear to the right of them in parentheses. The horizontal and vertical ordering of the linguistic elements and abbreviations corresponds to their relative placement in the clause, sentence, and text. Boldface is used to indicate the main burden of the signalling. Passé simple is abbreviated as PS, and PS+ points to the presence of more than one passé simple verb at that stage in the text. Affect (Aff) is included to highlight the systematic pattern of its presence/absence at the end of paragraphs; more affect is found overall in the text. 


\begin{tabular}{|c|c|c|c|c|}
\hline THEME: (TOPIC:) & (GIVEN/inferrable:) & & & \\
\hline Il fut un temps où... & & & & Aff \\
\hline $\begin{array}{l}\text { A cette époque lointaine, } \\
\text { Les années passèrent. }\end{array}$ & $\begin{array}{l}\text { trois jeunes filles } \\
\text { le chêne, il }\end{array}$ & PS & un chêne & Aff \\
\hline Au début & les hommes & & le chêne & \\
\hline $\begin{array}{l}\text { puis } \\
\text { (RHEME:) }\end{array}$ & ils & PS & & $-\mathbf{A f f}$ \\
\hline Un jour, & $\begin{array}{l}\text { un petit nuage } \\
\text { Les hommes }\end{array}$ & $\begin{array}{l}\text { PS+ } \\
\text { PS+ }\end{array}$ & $\begin{array}{l}\text { le chêne } \\
\text { le chêne }\end{array}$ & $\begin{array}{l}\text { Aff } \\
\text { Aff }\end{array}$ \\
\hline COMMENT: & & & & \\
\hline$\overline{\text { Alors }}$ & un tout petit homme & \multicolumn{3}{|c|}{ PS/presentational } \\
\hline & Il & PS+ & \multicolumn{2}{|l|}{ le chêne } \\
\hline $\begin{array}{l}\text { Aussitôt, } \\
\text { NEW: }\end{array}$ & les nuages, les astres & PS + & & \\
\hline$\overline{\text { Mais }}$ & quelques étoiles & PS & \multirow{2}{*}{\multicolumn{2}{|c|}{$\begin{array}{l}\text { le chêne } \\
\text { la Voie lactée }\end{array}$}} \\
\hline Ainsi & & PS & & \\
\hline
\end{tabular}

Figure 1. Linguistic signalling of structural, interactional, and cognitive shifts in discourse level information in the sample narrative

While sentence-level information structuring is related to the textual fit that the sentence brings with it, discourse-level information structuring is tied to the discourse as a whole and the triggers in the situational context. What the above analysis shows is that the three parameters are tied to different dimensions of discourse and they are signalled using linguistic cues that differ from one another. If the signals are not there, it may still be possible to single out the overall structure of the narrative, its text strategies, peak profile and tellability. But overt signalling of the three different kinds of shifts in discourse-level information structuring contributes to readability by clearly indicating the entry-point to the story (thus activating expectations of its overall structure), its culmination (an interactional shift facilitating the interpretation of what the weighty part of the story is), and last but not least, the point of telling the story (by indicating the locus of the main inferencing effort, expected to coincide with discourse-level newness, which consists of inactivated information).

In the analysis undertaken in section 4.2 , below, the concern is with narrative of a different kind, a news story, and the workings of information structuring at the level of a typographic paragraph.

\subsection{A news story paragraph}

Despite their genre label, "news stories" are not expected to be stories structured in terms of contingent temporal sequentiality. Even though news stories are about events constructed on the basis of human experience, the conventions of organizing such texts include a strong tendency towards breaking the chronology of the series of events in question (for news story structure, see e.g. Van Dijk, 1988). News stories may, however, manifest narrative passages, and it is, of course, not impossible to write 
the event at hand into the form of a temporally sequential "story" about (groups of) participants. But the narrative text type (related to form) is here put to indirect use, to serve the expository type of discourse (related to function; for discussions of the two levels, see e.g. Virtanen, 1992b, 20Io). It is therefore instructive to explore shifts in information-structuring in a news story narrative, too.

In [2], below, from the beginning of a news story (Lecocq, Morin, 2009), the textual work that the chains of temporal and locative expressions perform in the second paragraph is worth analysing in some detail for the information-structural interplay, within this paragraph, of the elements placed in initial and final positions in the sentence. And as above, due attention will be paid to participant continuity, tense-aspect variation and the occurrence of connectors. The paragraph under investigation is presented below together with its immediate textual context.

[2] Cet insecte fait perdre des milliards aux agriculteurs

Venue des États-Unis et débarquée en Europe au début des années 1990, la chrysomèle du maïs s'installe-t-elle en France? Diabrotica virgifera virgifera, de son nom latin, a été surnommée outre-Atlantique «the billion dollars bug» ('linsecte à 1 milliard de dollars), en raison des dégâts qu'elle occasionne: là où il n'est pas combattu, ce coléoptère peut faire baisser les rendements de $80 \%$.

Depuis le début de l'été, il a été piégé dans plusieurs régions de France. Il y avait fait des incursions répétées, mais jusqu'alors contenues, depuis sa détection, en 2002, près des aéroports parisiens. Le 13 août, la préfecture de Savoie a annoncé que plusieurs nouveaux foyers avaient été découverts. Des captures avaient déjà eu lieu, depuis juillet, en Haute-Savoie, dans l'Ain et le Rhône. Mais c'est l'Alsace qui est en première ligne, avec une multiplication des piégeages: quelque 150 insectes sur neuf foyers, contre quatorze individus sur trois foyers en 2008 , deux coléoptères piégés en 2007 et un seul en 2006.

Alors même que l'été n'est pas terminé, la découverte de nouveaux foyers, mais aussi de récidivistes là même où la lutte avait été menée les années passées, est une mauvaise nouvelle $[\ldots]$.

The three parameters of information structuring, grounded in structural, interactional and cognitive concerns, are conspicuously present also at paragraph level. Interpreting the opening sentence of the second paragraph as its theme, its positionally defined entry-point, leaves us with the rest of it as the rheme. The opening sentence is highly nuclear in the paragraph, characterized by its rich pattern of "lexical bonding" (Hoey, I99I), bonding sentences manifesting a minimum of three cohesive links. The opening sentence bonds lexically with all the other sentences in the paragraph, which is not the case with any of the other sentences. The salient member of the pair, theme, is introduced with a sentenceinitial adverbial of time depuis le début de l'été, followed by a pronominal reference to the continuous participant $(i l)$. End-weight is given to the locative specifying the geographical area that can be anticipated to constitute the "hypertheme" (Daneš, 
1974) of the paragraph (plusieurs régions de France). The paragraph-level rheme starts with a flashback, opening with co-referential links to the main participant and the locative as a whole, thus postponing the expected diversification of the regions.

After the specification of the elements of the paragraph-level topic in the first sentence, the second, flashback sentence, still part of the topic, provides a background against which the interactional shift to paragraph-level comment is all the more conspicuous. All the sentences of the comment part bond with one another lexically, but the second, flashback sentence is linked only to the first sentence of the paragraph. The beginning of the salient member of this pair of notions, comment, is signalled by the focused sentence-initial adverbial of time le I3 août, smaller in size and semantically different from the previous sentence-initial adverbial. At this point there is also a break in participant continuity, from the beetle to the Savoie authorities. And the sentence displays a shift from the preceding plus-que-parfait back to the passé composé of the news story narrative.

While the comment goes on, the paragraph-level boundary between given and new information coincides with the salient text-strategic break where the locative subject Alsace is marked as informationally new by the present tense cleft construction (c'est l'Alsace qui est en première ligne). This important boundary is thus signalled by linguistic means that differ from those found at the shifts from theme to rheme and from topic to comment: the connector mais, the sentence-initial locative carrying new information, and the implicitness of the reference to time (the "now" of the present tense), all jointly serve to introduce the focal point dealing with the situation at the moment of writing. This is the Figure-like, so far not activated piece of new information at paragraph level, to be infused into the activated information.

Like the shift to the weighty comment, this shift is also placed after a flashback sentence, the inactivated information thus being powerfully contrasted with the situation in the immediately preceding period of time, in an adjacent but separate group of geographical regions. Further, the new and focal information of increasing numbers of beetles and sites is subsequently highlighted through comparisons with the situation in Alsace in earlier years, reversing the chronology at the end of the paragraph-final sentence: quelque I5o insectes sur neuffoyers, contre quatorze individus sur trois foyers en 2008, deux coléoptères piégés en 2007 et un seul en 2006.

The paragraph under attention is thus instructive in terms of its temporal and locative structuring, the "here" and "now" having been established in the heading and the first sentence of the text. In this paragraph the main flow of temporal succession is maintained, even though the paragraph also incorporates two flashbacks and an instance of reversed chronology, in line with the news story conventions of breaking temporal sequentiality. The starting point of the chain of temporal signals is specified to be the beginning of the summer of 2009 , the writing taking place in mid-August: depuis le début de l'été. The temporal text strategy is then exhibited 
through another adverbial marker in initial position, le I3 août, which is followed by the implicit "now" of the cleft c'est [...] qui est [...]. The increasing level of detail in the temporal specifications is an indication of the deictic "me-first" phenomenon (cf. Ross, 1973): the temporal signals become more precise when approaching the writer's and (assumingly) reader's time. The implicitness of the non-past, conveyed by the present tense, allows for a non-temporal opening in the final sentence of the paragraph.

The chronology is, however, broken twice and finally reversed. After the temporal point of departure has been specified, the reader is brought back to a previous stage extending from the first discovery of the beetle in 2002 until the summer of 2009 , to contrast these contained incursions with the current new stage of the invasion. The second flashback takes place after the mentioning of the specific date of 13 August, concerning the discovery of new sites from the preceding month of July onwards. This is again contrasted with the situation of the time of writing, in the second half of August 2009, as indicated by the shift to the present tense in the subsequent sentence. The final sentence of the paragraph is rounded off with a reversed chronology from the current situation to the first discovery of the beetle in Alsace, which serves to emphasize the alarming situation in the region at the moment of writing.

It is important to note that the two flashback sentences involve non-initial placement of temporal elements. The first of them is introduced by a pronominal reference to the beetle, a locative place-holder for "several regions of France" and a plus-que-parfait verb, while the main temporal and locative specifications, those of the first discovery of the bug in the country, are given end-weight in the sentence (en 2002, près des aéroports parisiens). The second flashback starts with a general, full noun phrase reference to the catching of the bugs, des captures, an indexical link to the new sites mentioned at the end of the preceding sentence (plusieurs nouveaux foyers). Here, too, end-weight is given to the period of time as well as a series of regions of Eastern France (depuis juillet, en Haute-Savoie, dans l'Ain et le Rhône).

The chain of locative signals in this paragraph is introduced at the end of the opening sentence, plusieurs régions de France, picked up in the next (flashback) sentence $(y)$ that specifies the repeated but so far contained incursions, the trajectories having started from près des aéroports parisiens. The next locative signal, Savoie, is embedded in a prepositional phrase functioning as the subject of a reporting clause (la préfecture de Savoie). But the second flashback again moves the locatives to the end of their clause (en Haute-Savoie, dans l'Ain et le Rhône), only to single out l'Alsace through clefting at the outset of the next sentence, as the region that is en première ligne at the moment of writing. The regions of Eastern France are positioned one after the other in a structurally iconic fashion, the last of them differentiated by typographic load (sentence break), intrusion of a connector, and syntactic highlighting through clefting and tense shift. Placing locative signals 
early in the sentence (Savoie, Alsace) leaves the clause-final zone free for a series of references to the increasing number of infested sites (in reversed order: plusieurs nouveaux foyers - sur neuf foyers - sur trois foyers) as well as the growing number of the beetle culminating in Alsace, which is bearing the brunt of the attack (une multiplication des piégeages).

The main participant of the paragraph, the "billion-dollar bug", appears in the title of the news story (cet insecte) and the lead (the opening paragraph): $\varnothing$ - la cbrysomèle du maïs - elle - Diabrotica virgifera virgifera - elle - il - ce coléoptère. A discussion of the processing of the pronoun $i l$ as co-referential with the preceding elle lies beyond the scope of the present study. The first sentence of the second paragraph maintains participant continuity through a pronominal reference to the beetle $(i l)$, while the activation of the temporal text strategy in this paragraph takes place through the long sentence-initial adverbial of time. The second sentence also refers to the bug as $i l$, in subject position, but thereafter the sentence-initial reference is switched to the more "me-first" (human) collective body of authorities (la prefecture de Savoie), thus breaking the continuity of the participant-oriented text strategy. From this point onwards references to the beetle in the singular disappear; the concern is thereafter with infested sites and catchings (foyers, captures, piégeages) and the numbers of specimens caught (quelque 150 insectes, quatorze individus, deux coléoptères piégés, un seul). Only the subject des captures now appears sentence-initially, opening the second flashback of the paragraph.

The growing detail of the temporal frame as we move towards the implicitness of the moment of writing, as well as its conformity to "experiential iconicity" (Enkvist, 198I) across the three sentences introducing the paragraph-level theme, comment and new, facilitate processing of the temporal structure of the paragraph. By breaking the chronology, the two intervening flashback sentences reinforce the textual impact of the three major sentences, by providing a background for the paragraph-level theme, the beginning of the comment part, and the focal point. Sentence-initial adverbials of time open the paragraph-level theme and comment, otherwise appearing at the end of their sentences. The locatives of the paragraph are placed sentence-finally, only to move into an initial position as the text unfolds: the subject of the opening sentence of the comment part incorporates a specification of the location (Savoie), and the focal part highlights its locative subject Alsace by clefting. The chains of temporal and locative signals and their relative placement in the clause can be depicted as in Figure 2, these signals appearing in boldface. Boldface italics indicates a deviating signal in the sentence-initial zone: the subject embedding the locative Savoie, and the connector mais. Other temporal, locative and participant-oriented elements discussed above, as well as the clause-initial mais, are included for ease of readability, the variation between italics and non-italics here serving to distinguish between elements of different kinds. Those in parentheses form a local lexical link within one and the same sentence. The rest of the notation conventions are the same as in Figure $\mathrm{I}$. 


\begin{tabular}{|c|c|c|c|}
\hline THEME: (TOPIC:) & \multicolumn{3}{|l|}{ (GIVEN/inferrable:) } \\
\hline \multirow{2}{*}{$\begin{array}{l}\text { Depuis le début de l'été, } \\
\text { (RHEME:) } \\
\text { [flashback:] Il }\end{array}$} & il & \multicolumn{2}{|c|}{ dans plusieurs régions de France } \\
\hline & $\begin{array}{l}\text { (des incu } \\
\text { mais jusc }\end{array}$ & \multicolumn{2}{|c|}{$\begin{array}{l}\text { (des incursions répétées) } \\
\text { mais jusqu'alors ['début de l'été'] (contenues) } \\
\text { depuis sa détection, en 2002, } \\
\text { près des aéroports parisiens }\end{array}$} \\
\hline \multicolumn{4}{|l|}{ COMMENT: } \\
\hline \multicolumn{4}{|c|}{$\begin{array}{l}\text { plusieurs nouveaux foyers } \\
\text { depuis juillet, } \\
\text { en Haute-Savoie, dans l'Ain et le Rhône }\end{array}$} \\
\hline \multicolumn{4}{|l|}{$\begin{array}{l}\overline{\text { Mais }} \\
\text { 'now' }\end{array}$} \\
\hline [reversed chronology:] & $\begin{array}{l}\text { une multiplication des } \\
\text { quelque } 150 \text { insectes } \\
\text { quatorze individus } \\
\text { deux coléoptères } \\
\text { un seul }\end{array}$ & $\begin{array}{l}\text { iégeages } \\
\text { sur neuf foyers } \\
\text { sur trois foyers }\end{array}$ & $\begin{array}{l}\text { en } 2008 \\
\text { en } 2007 \\
\text { en } 2006\end{array}$ \\
\hline
\end{tabular}

Figure 2. Temporal and locative signals swapping places in a news story paragraph

\section{Comparing the two analyses}

In line with Östman and Virtanen (1999), three parameters of information structuring were distinguished on the discourse level, oriented towards structure, interaction and cognitive concerns. One of the members in each pair of concepts was interpreted as salient, Figure-like, against the indispensable Ground of the other: theme, comment, and new (with rheme, topic, and given/inferrable as Ground). The discourse-level shifts in information structuring along these three parameters were found to be signalled through linguistic means of different kinds in a highly context-sensitive fashion, in the two narratives analysed in some detail. Such signalling benefited from the chains of text-strategic adverbials of time indicating (dis)continuity in the narrative as well as other linguistic material placed in the sentence-initial slot, or immediately thereafter. Aggregates of signals of closure were also found to contribute to the shifting landscape of discourse-level information structuring.

One of the sample texts was a legend, an evocative text analysed in its entirety, while the other narrative comprised a paragraph in a news story, an informative text. The two narratives thus differed in terms of their genre (legend, news story), discourse function (narrative, expository) and their relation to the construction of a text world (evocative, informative). The scope of the analysis was also varied (entire text, paragraph). The theme of the news paragraph was related to the headline and lead, and some context was included in the example to show the continuation of the text, the next, non-narrative paragraph opening with another adverbial of time and a subject encapsulating the comment of the sample paragraph. 
The discourse-level theme was interpreted in positional terms, as the entry-point to the narrative. In the simple story the structural parameter of theme-rheme was related to the overall narrative schema, the lengthy theme thus corresponding to the orientation. Both themes started with a temporal marker: an absolute (i.e. context-independent) genre-marker in the legend, and at the outset of the news paragraph a lexically weighty adverbial of time relating to the moment of writing. The theme of the legend also manifested signals of closure, immediately preceding the starting point of the narrative proper. The opening sentence of the news paragraph ended in a possible hypertheme inviting anticipation of the continuation of the text, and it manifested lexical bonding with all the other sentences in the paragraph.

The discourse-level comment was identified in terms of the weighty part of the text (fragment), i.e. the peak of the simple story, and the information concerning the discovery of new sites in the news paragraph. The shifts to the discourse-level comment were signalled by linguistic cues that relied on the text strategies in use in the narrative while differing from the previous markers. In line with their discourse-functional differences, the legend employed a minimal signal of temporal juncture, empty of lexical content, while the news narrative made use of an absolute signal, a particular date. Yet, both temporal adverbials were smaller in size as compared with the preceding markers, and they were semantically more focused, narrowing down the window of time and referring to a different semantic set of temporal relations (from long periods to a moment of time; from years and months to a particular date). Other signals included a break in participant continuity, in both instances, as well as the syntactic cues of tense shift in the news paragraph and the presentational construction in the legend. The discourse-level comment of the legend was characterized by a change in pace and rhythm in the narration. All the comment sentences in the news paragraph were noted to bond with one another lexically, in contrast to its second sentence, which only manifested links to the opening sentence (the first two sentences functioning as the paragraph-level topic).

Discourse-level newness was related to the point of the story, the unexpected twist at its end. In the news story paragraph, newness was tied to the temporal goal of the paragraph, the situation at the moment of writing. In both samples newness was signalled by the connector mais. Connectors are rare in stories; in news stories, however, they can be more readily expected because of the indirect use of the narrative text type (form) to realize the expository discourse type (function). What is crucial is that in both samples the sentence-initial marker of this shift was completely different from those employed earlier. In the news paragraph newness was also signalled by a locative subject in a present tense cleft construction. The focal point of the story was reinforced by the coda, closing the narrative frame of time; in the news paragraph, the reversed chronology starting from the time of writing forcefully highlighted the current situation through comparison. 
The analyses showed differences in the signalling of the three Figure-like notions, which can be explained by the discourse function and genre of the texts as well as their evocative or informative orientation. But the signalling of information-structuring shifts also exhibited shared characteristics: the very high context-sensitivity of their markers as well as the different ways in which the discourse-level comment and new were singled out.

\section{Conclusion}

The linguistic signalling of structural, interactional and cognitive shifts in narrative readily incorporates cues to discourse type, genre and the assumed relationship of the text to the construction of text worlds (i.e. their evocative or informative orientation). But different kinds of narratives also manifest similarities in the high level of context-sensitivity of the signalling of information-structural shifts along the three parameters. This is the case irrespective of the textual scope of the narrative.

The positional discourse-level theme is the entry-point to the narrative, and some marking of closure can be expected in this Figure-like member of the structural pair. The closure can, however, vary from overt to very subtle (as in openings in medias res). The interactional discourse-level comment, again, relies on the text strategies already in use in the particular narrative but the shift is singled out by linguistic markers that differ from the preceding ones. They can be smaller in size and semantically more focused, as compared with the preceding markers. Further, the cognitively oriented discourse-level newness is marked using linguistic cues that deviate in kind from what is employed elsewhere in the text. The signalling of newness does not benefit from the possible linguistic variation within the activated narrative strategies; instead, even the differing nature of the linguistic signalling reflects the inactivated character of the information conveyed at the focal point of the narrative.

The above discussion suggests new avenues to the context-sensitive investigation of the linguistic signalling of discourse-level information structuring in narrative texts, in terms of the salient concepts of theme, comment, and new, pertaining to the structural, interactional and cognitive parameters of the umbrella notion. Comparisons across narratives of various kinds are likely to disclose patterns of signalling that conform to the discourse type (related to function) that these texts serve to realize (e.g. narrative, exposition, instruction). And genre-based investigations (e.g. legend, fable, joke, news story) might be expected to point to reliance on constructions involving conventionalized adverbial markers, and other sentence-initial elements, to indicate structural and interactional shifts on the discourse level, while cognitive newness might again be signalled through differing linguistic means. Further, non-narrative writing awaits investigations of discourse-level information structuring, in its own right. 
In particular, the present analyses suggest that discourse-level newness is signalled in narrative by markers that differ more radically from what is used earlier in the text than is the case with the discourse-level comment. The signalling of discourse-level comment, in contrast, rather seems to benefit from possible linguistic variation in conveying the text strategies that are activated in the text. The variation in size and semantic focus manifest in the sample narratives might thus profitably be examined in more data. Another issue worth investigating concerns the different ways of signalling closure of the discourse-level theme. Further, there appear to be differences in the information-structural landscape concerning the shift to the backgrounded discourse-level rheme, as compared to the shifts within the other two parameters, in one and the same text.

A closing word concerning the rationale behind the analysis is in order. The three parameters of information structuring were related to different discourse dimensions, for which models of analysis already exist. If the parameters and the dimensions are found to be, not concomitant, but one and the same textual phenomenon, Occam's Razor will be called for. Irrespective of this issue, however, the present analysis serves its purpose of extending information-structural notions to the discourse level, bringing under one and the same umbrella three parameters that are based on very different notions (structure, interaction, and cognition), and approaching the two members of the pairs of concepts from the perspective of Figure-Ground distinctions.

\section{Acknowledgements}

I am grateful to the two reviewers, the editors of the journal, the participants of the LPTS conference 2I-23 September, 2009, and the LaTTiCe research seminar 2 November, 20IO, both in Paris, for their insightful comments and constructive suggestions. All the shortcomings are, of course, mine. Thanks are also due to Mai Ho-Dac for translating the abstract into French and contacting the copyright holders of the two sample texts.

\section{References}

\section{Texts}

LeCoce, L. \& Morin, H. 2009. Cet insecte fait perdre des milliards aux agriculteurs. Le Monde, i8 August.

RaGACHE, C.-C. 1989. La création du monde: mythes et légendes. Paris: Hachette.

\section{Studies}

Chafe, W. 1994. Discourse, Consciousness, and Time: The Flow and Displacement of Conscious Experience in Speaking and Writing. Chicago: The University of Chicago Press. 
Charolles, M. 2006. “Un jour” (“one day”) in Narratives. In I. Korzen \& L. LundQuist (eds), Comparing Anaphors. Between Sentences, Texts and Languages. Copenhagen: Samfundslitteratur Press: II-26.

Charolles, M. et al. 2005. Temporal and Spatial Dimensions of Discourse Organisation. Journal of French Language Studies: Special Issue on Discourse Organisation through Time and Space I5 (2): II5-I3O.

Daneš, F. 1974. Functional Sentence Perspective and the Organization of the Text. In F. Daneš (ed.), Papers on Functional Sentence Perspective. Prague: Academia: Io6-I28.

Enkvist, N.E. 198I. Experiential Iconicism in Text Strategy. Text I (I): 97-III.

Enkvist, N.E. 1985. A Parametric View of Word Order. In E. Sözer (ed.), Text Connexity, Text Coherence: Aspects, Methods, Results. Hamburg: Helmut Buske: 320-336.

Enkvist, N.E. 1987. Text Strategies - Single, Dual, Multiple. In R. SteEle \& T. Threadgold (eds), Language Topics: Essays in Honour of Michael Halliday. Amsterdam - Philadelphia: John Benjamins: 203-2II.

Enkvist, N.E. 1989. Connexity, Interpretability, Universes of Discourse, and Text Worlds. In S. Allén (ed.), Possible Worlds in Humanities, Arts and Sciences. Berlin - New York: W. de Gruyter: I62-I86.

Firbas, J. 1992. Functional Sentence Perspective in Written and Spoken Communication. Cambridge: Cambridge University Press.

Fleischman, S. 1990. Tense and Narrativity: From Medieval Performance to Modern Fiction. Austin: University of Texas Press.

Halliday, M.A.K. 1985. An Introduction to Functional Grammar. London: Edward Arnold. Hoey, M. 1991. Patterns of Lexis in Text. Oxford: Oxford University Press.

Hunston, S. \& Thompson, G. 200I. Evaluation in Text: Authorial Stance and the Construction of Discourse. Oxford: Oxford University Press.

Laвоv, W. 1972. Language in the Inner City: Studies in the Black English Vernacular. Philadelphia: The University of Philadephia Press.

Lindholm, L. 20Io. “A Little Story for Food for Thought...”: Narratives in Advice Discourse. In S.-K. Tanskanen et al. (eds), Discourses in Interaction. Amsterdam - Philadelphia: John Benjamins: 223-236.

Longacre, R.E. 1983. The Grammar of Discourse. New York: Plenum Press.

Lyons, J. 1963. Structural Semantics. Oxford: Publications of the Philological Society.

Ochs, E. \& CAPps, L. 200I. Living Narrative: Creating Lives in Everyday Storytelling. Cambridge (Mass.): Harvard University Press.

Östman, J-O. \& Virtanen, T. 1999. Theme, Comment and Newness as Figures in Information Structuring. In K. Van Hoek, A.A. Kibrik \& L. Noordman (eds), Discourse Studies in Cognitive Linguistics. Amsterdam - Philadelphia: John Benjamins: 9I-IIO.

Prince, E.F. 1981. Toward a Taxonomy of Given-New Information. In P. Cole (ed.), Radical Pragmatics. New York: Academic Press: 223-255.

Ross, J.R. 1973. The Penthouse Principle and the Order of Constituents. In C. Corum (ed.), You Take the High Node and I'll take the Low Node: Papers from the Comparative Syntax Festival. Chicago: Chicago Linguistic Society: 379-422.

URL : http://discours.revues.org/8476 
Swales, J.M. 1990. Genre Analysis. Cambridge: Cambridge University Press.

VAn Dijk, T.A. 1988. News as Discourse. Hillsdale (N.J.): Lawrence Erlbaum.

VAN DijK, T.A. \& Kintsch, W. 1983. Strategies of Discourse Comprehension. New York: Academic Press.

Virtanen, T. 1992a. Discourse Functions of Adverbial Placement in English: Clause-Initial Adverbials of Time and Place in Narratives and Procedural Place Descriptions. Åbo: Åbo Akademi University Press.

Virtanen, T. 1992b. Issues of Text Typology: Narrative - a "Basic" Type of Text? Text I2: 293-310.

Virtanen, T. 2004. Point of Departure: Cognitive Aspects of Sentence-Initial Adverbials. In T. Virtanen (ed.), Approaches to Cognition through Text and Discourse. Berlin - New York: Mouton de Gruyter: 79-97.

Virtanen, T. 20Io. Variation across Texts and Discourses: Theoretical and Methodological Perspectives on Text Type and Genre. In H. Dorgeloh \& A. Wanner (eds), Syntactic Variation and Genre. Berlin - New York: Mouton de Gruyter: 53-84.

WÅrviK, B. 1990. On the History of Grounding Markers in English Narrative: Style or Typology? In H. Andersen \& K. Koerner (eds), Historical Linguistics 1987: Papers from the $8^{\text {th }}$ International Conference on Historical Linguistics. Amsterdam - Philadelphia: John Benjamins: 53I-542.

WÅrIK, B. 2004. What is Foregrounded in Narratives? Hypotheses for the Cognitive Basis of Foregrounding. In T. Virtanen (ed.), Approaches to Cognition through Text and Discourse. Berlin - New York: Mouton de Gruyter: 99-122. 